\title{
Potential role of dendritic cell vaccination with MAGE peptides in gastrointestinal carcinomas
}

\author{
FUMIAKI TANAKA, NAOTSUGU HARAGUCHI, KENJI ISIKAWA, HIROSHI INOUE and MASAKI MORI
}

Department of Surgery, Medical Institute of Bioregulation, Kyushu University, Beppu 874-0838, Japan

Received May 27, 2008; Accepted July 12, 2008

DOI: 10.3892/or_00000117

\begin{abstract}
Dendritic cells (DCs) loaded with tumor antigens have been emerging as a new strategy in cancer treatment. The $M A G E$ genes are selectively expressed in a variety of cancer tissues such as melanoma or gastrointestinal carcinomas. However, no expression is observed in normal tissues except testis. There are several reports on clinical trials with these immunogenic peptides including MAGE gene-derived, which were shown to be effective for some patients with carcinomas. We previously reported a clinical trial treating gastrointestinal carcinoma patients with immature DC and MAGE peptides via intravenous injection. Autologous DCs were generated ex vivo and were pulsed with MAGE-3 peptide, depending on the patient's HLA haplotype (HLA-A02 or A24). In this study, patients were immunized with mature DCs pulsed with the MAGE-3 peptide four times every 2 weeks via s.c. injection close to the axilla and inguinal lymph nodes. Twenty-eight patients with advanced gastrointestinal carcinoma were treated and no toxic side effects were observed. Peptide-specific CTL responses, improvement in performance status, tumor marker decrease and minor tumor regressions after vaccination were observed in some patients. These results suggested that DC vaccination with the MAGE-3 peptide would be safe and can exhibit antitumor effects even in the patients with advanced gastrointestinal carcinoma who were previously treated with chemotherapy or radiation therapy.
\end{abstract}

\section{Introduction}

New therapeutic strategies are required for many inoperable and recurrent cancers due to the lack of effective treatment.

Correspondence to: Professor Masaki Mori, Department of Surgery, Medical Institute of Bioregulation, Kyushu University, 4546 Tsurumihara, Beppu 874-0838, Japan

E-mail: mmori@beppu.kyushu-u.ac.jp

Abbreviations: DC, dendritic cell; PBMC, peripheral blood mononuclear cell; IL, interleukin; CEA, carcinoembryonic antigen; CA19-9, carbohydrate antigen 19-9; SCC, squamous cell carcinoma antigen; PD, progressive disease; MR, minor response; DTH, delayed type hypersensitivity; Th, helper T cells

Key words: dendritic cell, MAGE peptides, gastrointestinal carcinomas
Gastrointestinal cancers are common malignant tumors and are also a major cause of cancer-related death in the world $(1,2)$. Most patients who undergo surgery for advanced stage gastrointestinal carcinomas are still at high risk of local or systemic recurrence. Recently, chemotherapy has been improved for treatment of patients with advanced colorectal cancer. However, there is no standard therapy including chemotherapy or radiotherapy for advanced or recurrent variety of gastrointestinal cancers. Thus, there is a great need for novel therapeutic approaches for patients with advanced or recurrent gastrointestinal carcinomas.

The expression of the $M A G E$ genes was observed in tumors of various histological origins, whereas no expression has been observed in normal tissues except testis (3). Several reports exist on the successful induction of HLA class Irestricted antitumor CTLs using MAGE peptides (4-8). These tumor antigen-peptides seem to be potential targets for tumor-specific immunotherapy (9-11).

Dendritic cells (DCs), antigen-presenting cells, which were the most capable of priming naive T cells to CTLs, have been demonstrated to induce potent antitumor immunity in vitro and in vivo (12). By using the efficacy of DCs, clinical trials using DCs have been studied as an active immunotherapy against a variety of carcinoma including malignant melanoma. DC vaccination induced tumor-specific immune responses and also tumor regression in clinical trials for several types of carcinomas (13-15).

We previously reported DC vaccination with HLArestricted MAGE-3 peptide for patients with gastrointestinal carcinoma in twelve patients (16). No toxicity was found in any patient and the immune response for MAGE-3 peptide and tumor regression was observed in some patients who had advanced metastatic gastrointestinal carcinoma. Based on our previous study, we continued the DC vaccination with HLArestricted MAGE-3 or MAGE-1 peptides in 28 patients with gastrointestinal carcinoma. This study summarizes the results; no toxicity was found in any patient and the immune response for MAGE peptide and tumor regression was observed in some patients who had advanced metastatic gastrointestinal carcinoma.

\section{Patients and methods}

Patients. The study protocol was approved by the Clinic Institutional Ethics Review Boards of the Medical Institute of Bioregulation, Kyushu University and written consent was obtained from all the patients at the time of enrollment. 
According to the protocol, patients were required: a) to be HLA-A2 (0201) or HLA-A24 (2402)-positive; b) to have histologically confirmed primary or metastatic lesions of gastrointestinal carcinoma expressing $M A G E-3$ mRNA by reverse transcription-PCR (17); c) to have adequate cardiac, pulmonary, hepatic, renal and hematological functions; and d) to have an ECOG performance status of 0 to 2. Furthermore, patients were excluded a) with any severe infectious, hematological, cardiac and pulmonary diseases; b) with radiation therapy, chemotherapy, or immunotherapy within the prior 4 weeks; c) with steroid therapy; and d) in pregnancy. Treatment was carried out at the Department of Surgery, Medical Institute of Bioregulation, Kyushu University from January 1997 through August 2006.

Generation of DCs. Patients underwent leukapheresis using a cell separator (MULTI; Hemonetics Co., Braintree, MA). PBMCs isolated by Ficoll-Paque (Amersham Pharmacia Biotech, Piscataway, NJ) were separated by adherence to a plastic tissue culture flask to enrich the monocyte fraction. After $90 \mathrm{~min}$ at $37^{\circ} \mathrm{C}$, nonadherent cells were removed and adherent cells were subsequently cultured for 7 days with $1000 \mathrm{U} / \mathrm{ml}$ of granulocyte macrophage colony-stimulating factor (NCPC-GeneTech, Shijiazhuang, P.R. China) and $1000 \mathrm{U} / \mathrm{ml}$ of IL-4 (R\&D system, Minneapolis, MN) in RPMI with 5\% autologous serum. On day 6, OK432 (0.1 KE/ $\mathrm{ml}$ ) (Chugai Co., Osaka, Japan) was added to the culture medium for 2 days to induce maturation of the DCs. After 7 days, the DCs were harvested by vigorous washing from the flask and the remaining cells were removed with cell dissociation buffer (Life Technologies, Inc., Gaithersburg, MD). Cultured DCs were monitored by light microscopy. Flow cytometric analysis was performed using a FACScan (Becton Dickinson) with antibodies against mouse antihuman HLA-class I (Immunotech, Marseille, France), HLA-DR (Immunotech), CD80 (Ancell, Bayport, MN), CD86 (Ancell), or CD14 (Becton Dickinson, San Jose, CA). FITC-conjugated rabbit antimouse $\mathrm{IgG}$ was used as the second antibody (Dako Japan Co., Ltd., Kyoto, Japan).

Pulsing of in vitro generated DCs. Generated DCs were resuspended at $1 \times 10^{6}$ cells $/ \mathrm{ml}$ normal saline with $1 \%$ human albumin. DCs were pulsed with $10 \mu \mathrm{g} / \mathrm{ml}$ of MAGE-3 peptide for HLA-A2 (FLWGPRALV) (6) and for HLA-A24 (IMPKAGLLI) (8), was synthesized and purified (>95\% purity) by Mutiple Peptide System (San Diego, CA) for $4 \mathrm{~h}$ at room temperature.

Patient treatment. The standard vaccination schedules were as follows. Four vaccinations with MAGE-3 peptide-pulsed DCs were administered at 14-day intervals. Seven days before each vaccination, patients underwent leukapheresis for DC set up. Physical and hematological examinations were monitored before and after each vaccination. The DC vaccines were immunized with $3 \times 10^{7}$ cells (pulsed with $300 \mu \mathrm{g}$ of peptide) $/ 1.6 \mathrm{ml}$ normal saline. The patients were to receive the DC s.c. every 2 weeks for four immunizations (Fig. 1). Toxicity was graded using the National Cancer InstituteCommon Toxicity Criteria. Tumor markers [carcinoembryonic antigen (CEA), CA19-9 and SCC] and imaging studies (computed tomography scans and chest radiographs) were reviewed as available before, during and after the four immunization protocols to determine the clinical response. Standard definitions of major objective responses (complete response, partial response, no change, or PD) were used. MR was defined as a 25 to $50 \%$ decrease of lesions in at least 1 month or a $>50 \%$ decrease of lesions lasting less than a month. Performance status was re-evaluated at the end of treatment according to the ECOG scale.

Immunological response. Blood samples were collected for assessment of CTL precursors from the first leukapheresis and the fourth leukapheresis and PBMCs were separated by centrifugation on a Ficoll-Paque density gradient. PBMC preparations were frozen in FCS with $10 \%$ DMSO. CTL assay was performed according to the protocol, as described (18). Briefly, 4x106 PBMCs/ml were incubated in RPMI-1640 with $5 \%$ heat-inactivated human serum in 24-well plates in the presence of $20 \mu \mathrm{g} / \mathrm{ml}$ MAGE-3 peptide. On day 1, recombinant interleukin-2 (Takeda Co., Ltd., Osaka, Japan) was added to the culture at $30 \mathrm{IU} / \mathrm{ml}$. On day 7 , cells were centrifuged and resuspended at $5 \times 10^{5}$ cells $/ \mathrm{ml}$ in the presence of $1 \times 10^{6}$ cells $/ \mathrm{ml}$ peptide-pulsed PBMCs and $30 \mathrm{IU} / \mathrm{ml} \mathrm{IL}-2$ was added on day 8. Peptide-pulsed PBMCs were pretreated with mitomycin C (Kyowa Hakko, Osaka, Japan). The CTL activities were tested on day 14 . The target peptide-pulsed cell lines, 221(A2.1) [HLA-A2 (+), MAGE-3 (-)] for HLA-A2 and TISI [HLA-A24 (+), MAGE-3 (-)] for HLA-A24 (both cell lines were provided by Takara Shuzo Co. Ltd.) were prepared by incubating the cells with the peptides $(20 \mu \mathrm{g} / \mathrm{ml})$ overnight at $37^{\circ} \mathrm{C}$. The target cancer cell lines, the gastric carcinoma cell line KATO III [HLA-A2(+), -A24 (-), MAGE-3 (+)], the colon carcinoma cell line WiDr [HLA-A24(+), MAGE-3(+)] and the lymphoma cell line Raji [HLA-A2(-), A24(-), MAGE-3 (-)] were provided Japanese Cancer Research Bank (Tokyo, Japan). These cells were labeled with $100 \mu \mathrm{Ci}$ of sodium 51 chromate $\left({ }^{51} \mathrm{Cr}\right)$ for $1 \mathrm{~h}$ at $37^{\circ} \mathrm{C}$ and the labeled cells were then washed and resuspended. The effecter cells were placed in each well of round-bottomed microtiter plates. The labeled target cells were then added to the well at a concentration of $3 \times 10^{3}$ cells/well to produce a total volume of $0.2 \mathrm{ml}$. After a 4-h incubation period, the release of ${ }^{51} \mathrm{Cr}$ label was measured by collecting the supernatant, followed by quantitation in an automated gamma counter. The percentage of specific cytotoxicity was calculated as the percentage of specific ${ }^{51} \mathrm{Cr}$ release: $100 \mathrm{x}$ (experimental release - spontaneous release)/(maximum release - spontaneous release). To eliminate any nonspecific lysis attributable to natural killer-like effectors, the cytolytic activity was tested in the presence of a 30 -fold excess of unlabeled K562 cells.

DTH skin tests were performed with peptide before vaccination and after the four-immunization protocol. Patients were injected with $10 \mu \mathrm{g}$ of peptide (100- $\mu$ l final volume) intradermally at disease-free sites. A positive skin test reaction was defined as palpable skin indurations of at least $4 \mathrm{~mm}$ in diameter combined with erythema of at least the same size at the site of peptide inoculation after $48 \mathrm{~h}$ (19).

Flow cytometric determination of IFN and IL-4 in the cytoplasm of peripheral CD4-positive T cells was performed, as described (20). Briefly, the patient's CD4-positive T cells 


\section{Protocol of DC/MAGE peptide vaccine}

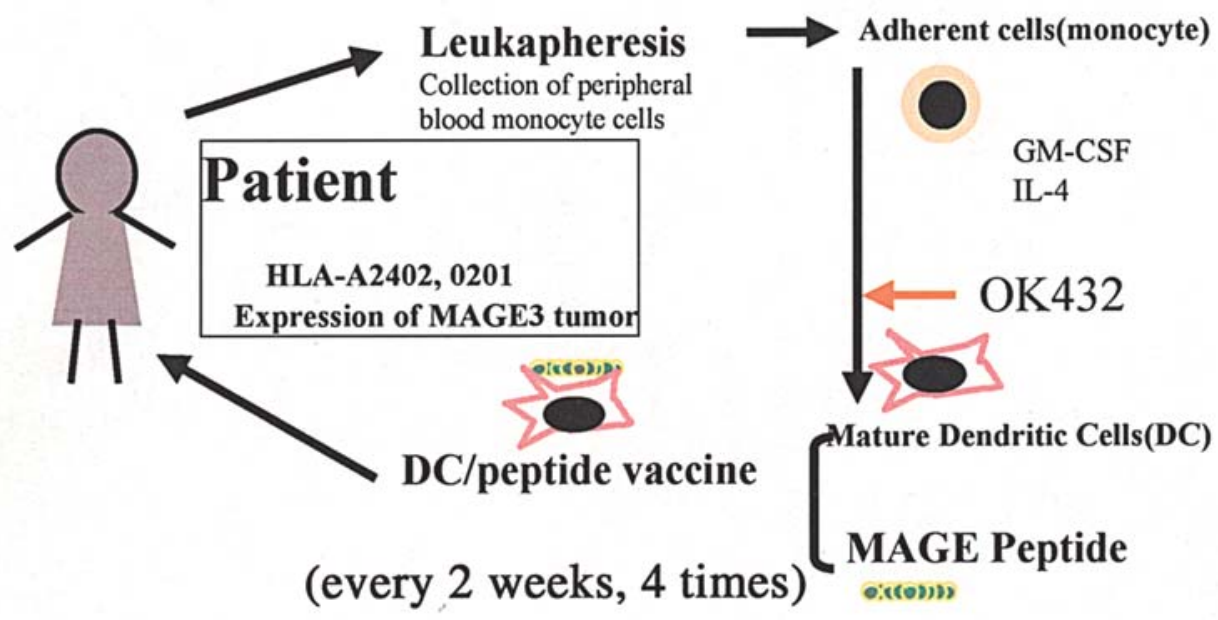

Figure 1. Protocol of DC/MAGE peptide vaccine. When a patient has expression of MAGE and HLA-A2402 or 0201, peripheral monocyte cells were collected and dendritic cells were generated using GM-CSF, IL-4 and OK432. MAGE peptide and DCs were co-cultured with DC, then the DC/peptide was injected into axiller and inguinal lymh nodes. This vaccine was repeated every 2 weeks and completed with injection (4 times).

were continuously treated with fluorescence-activated cell sorter lysing and permeabilization solutions (Becton Dickinson Immunocytometry System; Becton Dickinson). The cells were subsequently incubated with FITC-conjugated anti-IFN- and phycoerythrin-conjugated anti-IL-4 (Becton Dickinson) in $0.1 \%$ BSA-PBS. FITC-mouse $\operatorname{IgG}_{2}$ a and phycoerythrin-mouse $\mathrm{IgG}_{1}$ (Becton Dickinson) were used as controls. The percentage of cells positive for IFN and IL-4 were counted and evaluated with a FACScan (Becton Dickinson).

Immunohistochemistry. Serial paraffin-embedded tissue sections of carcinoma tissues were stained with monoclonal antibodies against MAGE-3 (57B; kindly provided by Dr Giulio Spagnoli, University Hospital, Basel, Switzerland), T cells (UCHL-1; Dako), CD8 (C8/144B; Nichirei Co., Tokyo, Japan), or CD4 (1F6; Nichirei Co.). Primary antibody was detected with Dako LSAB kit, Peroxidase (Dako). Diaminobenzidine tetrahydrochloride was used as the chromogen. Then, the sections were counterstained with hematoxylin.

\section{Results}

Patients. The characteristics of the 28 patients initially enrolled in the study are summarized in Table I. All of the patients had MAGE-3-expressing advanced gastrointestinal carcinomas originating from the stomach (ten patients), esophagus (eight patients), colon (seven patients), gall bladder (two patients) and pancreas (one patient).

DCs. The collected PBMCs were $1.31 \pm 0.42 \times 10^{9}$ cells after each leukapheresis and Ficoll separation. To generate DCs from PBMCs, $15.51 \pm 0.5 \times 10^{7}$ PBMCs were plated and after 7-day culture, $3.51 \pm 0.49 \times 10^{7}$ cells were obtained with $95 \%$ viability. By morphology, the harvested population of cells was $72 \pm 13 \%$ large dendritic-like cells and $18 \pm 8 \%$ small lymphoid-like cells. DCs expressed high levels of HLA class I, class II, CD80, CD86 and low CD14 by flow cytometry (data not shown).

Toxicity. The vaccination protocols were well tolerated. There were no acute toxicities during or immediately after the s.c. DC injection. No hematological, hepatic, pulmonary, or renal toxicities were observed in any patients (Table I).

Immunological response. Aliquots of PBMCs, frozen at the first leukapheresis and the fourth leukapheresis, were thawed at the same time and subjected to the assay for CTL precursors. We evaluated the CTL response for eight patients. A CTL response was considered to be positive with a peptide-specific lytic activity $>20 \%$ at an E:T ratio of $80: 1$ or $40: 1$. Results from our preliminary test series indicated that a target lysis of $20 \%$ (E:T, $80: 1$ or $40: 1)$ was a suitable cutoff to evaluate the peptide-specific lysis (8). Before vaccination, CTL precursor frequencies were low or undetectable. On the other hand, the peptide-specific CTL responses were observed in four out of eight patients after vaccination (Fig. 2).

Peptide-specific DTH reactions were not observed before vaccination in any patient; however, there were eight patients in which we observed DTH reactions after the fourth vaccination (Table I). Intracellular cytokine analysis was performed for twenty-two patients. In eight of the 22 patients, the ratio of IFN- $\gamma$ :IL-4 of CD4-positive cells increased after vaccination compared with before vaccination (Table I).

Clinical response. Table I summarizes the clinical response for the 28 patients. In eleven patients, tumor markers (CEA, CA19-9 or SCC) decreased after the first or second vaccination compared with before treatment. Regression of tumor was observed in four patients. In one case, metastatic 
Table I. Patient records.

\begin{tabular}{|c|c|c|c|c|c|c|c|c|}
\hline Case & Primary site & Metastasis & Pre-treat & Side effect & Tumor marker & Antitumor effect & Better QOL & Th1/Th2 \\
\hline 1 & Esophagus & Neck LN & $S, C, R$ & No & Down & MR & Yes & Up \\
\hline 2 & Esophagus & Neck LN & $\mathrm{C}, \mathrm{R}$ & No & $\mathrm{Up}$ & PD & $\mathrm{NC}$ & Down \\
\hline 3 & Esophagus & Abd LN & $\mathrm{C}, \mathrm{R}$ & No & Down & MR & Yes & N.D. \\
\hline 4 & Stomach & Peritoneum & $\mathrm{S}, \mathrm{C}$ & No & Down & PD & Yes & N.D. \\
\hline 5 & Stomach & Peritoneum, liver & $\mathrm{S}, \mathrm{C}$ & No & Up & PD & No & N.D. \\
\hline 6 & Stomach & Peritonuem, wall & $S, C$ & No & Down & PD & No & N.D. \\
\hline 7 & Stomach & Lung & $\mathrm{S}, \mathrm{C}$ & No & Down & PD & No & N.D. \\
\hline 8 & Stomach & Liver & $\mathrm{S}, \mathrm{C}$ & No & Down & PD & $\mathrm{NC}$ & N.D. \\
\hline 9 & Stomach & Liver, abd wall & $\mathrm{S}, \mathrm{C}$ & No & Up & PD & No & Down \\
\hline 10 & Colorectal & Lung, chast wall & $\mathrm{S}, \mathrm{C}$ & No & Down & MR & Yes & Up \\
\hline 11 & Colorectal & Liver & $\mathrm{S}, \mathrm{C}$ & No & Up & PD & $\mathrm{NC}$ & Down \\
\hline 12 & Colorectal & Bone & $\mathrm{S}, \mathrm{C}$ & No & Up & PD & $\mathrm{NC}$ & Up \\
\hline 13 & Stomach & Abd LN & $\mathrm{S}, \mathrm{C}$ & No & Up & PD & No & Down \\
\hline 14 & Stomach & Bone & $\mathrm{S}, \mathrm{C}$ & No & Down & PD & No & Down \\
\hline 15 & Stomach & Peritoneum & $\mathrm{S}, \mathrm{C}$ & No & Up & PD & No & Down \\
\hline 16 & Colorectal & Liver, abd LN & $\mathrm{S}, \mathrm{C}$ & No & Down & $\mathrm{NC}$ & $\mathrm{NC}$ & Dp \\
\hline 17 & Gall Bladder & Lung, abd LN & $S, C$ & No & Down & MR & $\mathrm{NC}$ & Up \\
\hline 18 & Colorectal & Liver, abd LN & $\mathrm{S}, \mathrm{C}$ & No & Up & PD & No & Down \\
\hline 19 & Stomach & Abd LN & $\mathrm{S}, \mathrm{C}$ & No & Up & PD & No & Down \\
\hline 20 & Esophagus & Neck LN & $\mathrm{S}, \mathrm{C}, \mathrm{R}$ & No & Up & PD & No & Down \\
\hline 21 & Esophagus & Liver & $\mathrm{S}, \mathrm{C}$ & No & Up & PD & $\mathrm{NC}$ & Up \\
\hline 22 & Colorectal & Local, abd LN & $\mathrm{S}, \mathrm{C}$ & No & Up & PD & No & Down \\
\hline 23 & Pancreas & Liver, local & $\mathrm{S}, \mathrm{C}$ & No & Up & PD & $\mathrm{NC}$ & Up \\
\hline 24 & Esophagus & Liver & $\mathrm{C}, \mathrm{R}$ & No & Down & PD & No & Down \\
\hline 25 & Gall Bladder & Liver, abd wall & $\mathrm{S}, \mathrm{C}$ & No & $\mathrm{Up}$ & PD & $\mathrm{NC}$ & Down \\
\hline 26 & Colorectal & Abd LN & $\mathrm{S}, \mathrm{C}, \mathrm{R}$ & No & $\mathrm{Up}$ & PD & Yes & $\mathrm{Up}$ \\
\hline 27 & Esophagus & Chest & $\mathrm{S}, \mathrm{C}$ & No & $\mathrm{Up}$ & PD & $\mathrm{NC}$ & Down \\
\hline 28 & Esophagus & Chest & $\mathrm{S}, \mathrm{C}, \mathrm{R}$ & No & $\mathrm{NC}$ & PD & Yes & Down \\
\hline
\end{tabular}

LN, lymph node; Abd, abdominal; S, surgery; C, chemotherapy; R, radiation therapy and NC, no change.

lesions of supraclavicular lymph nodes regressed after the second vaccine and also the hoarseness was improved. In another case, metastatic lymph nodes that were resistant to prior chemotherapy and irradiation regressed and esophagectomy was performed after the DC vaccine protocol. In another case, atelectasis of the left lung improved. Six patients showed an improvement in performance status and four patients maintained the performance status compared with their status pretreatment. Twenty-four out of 28 patients felt some pain at the site of DCs/peptide complex on injection day. However, all patients recovered the following day.

\section{Discussion}

In this study, the mature DC vaccines with MAGE peptide injection were well tolerated with low toxicity. The results were consistent with our previous study and others (21-24). As we performed a dose escalation study in our previous study, we fixed the vaccine-cell number (30 million DCs/injection).

Gastrointestinal carcinomas, such as esophageal, gastric and colorectal carcinomas may be curable by surgery, though the cure rate is moderate to poor depending on the extent of the disease. Regarding gall bladder carcinoma and pancreatic cancer, it is very difficult to treat them by surgery alone $(25,26)$. Chemotherapy may have some benefit especially for colorectal cancer. However, there is no standard regimen for advanced gastrointestinal carcinomas, especially for upper gastrointestinal cancer. Adverse events sometimes occur. Thus, cancer immunotherapy for gastrointestinal carcinomas could be an alternative treatment approach. Compared to our previous study, we changed these points; i) use of mature DCs from immature DCs and ii) i.v. injection to s.c. injection. To protect generating auto-immune reaction, and avoiding the state of anergy to tumor immunity, using mature DCs is an important factor (27). Injection of s.c. would be more effective and available for trafficking to 'regional lymph node' than that of i.v. injection. These changes might be reflected in the increase in percentage of DTH-positive patients.

The expression of the MAGE genes was observed in tumors of various histological origins, whereas no expression has been observed in normal tissues except testis (3). Testis cells do not express MHC class I molecules, thus, they do 
(A)
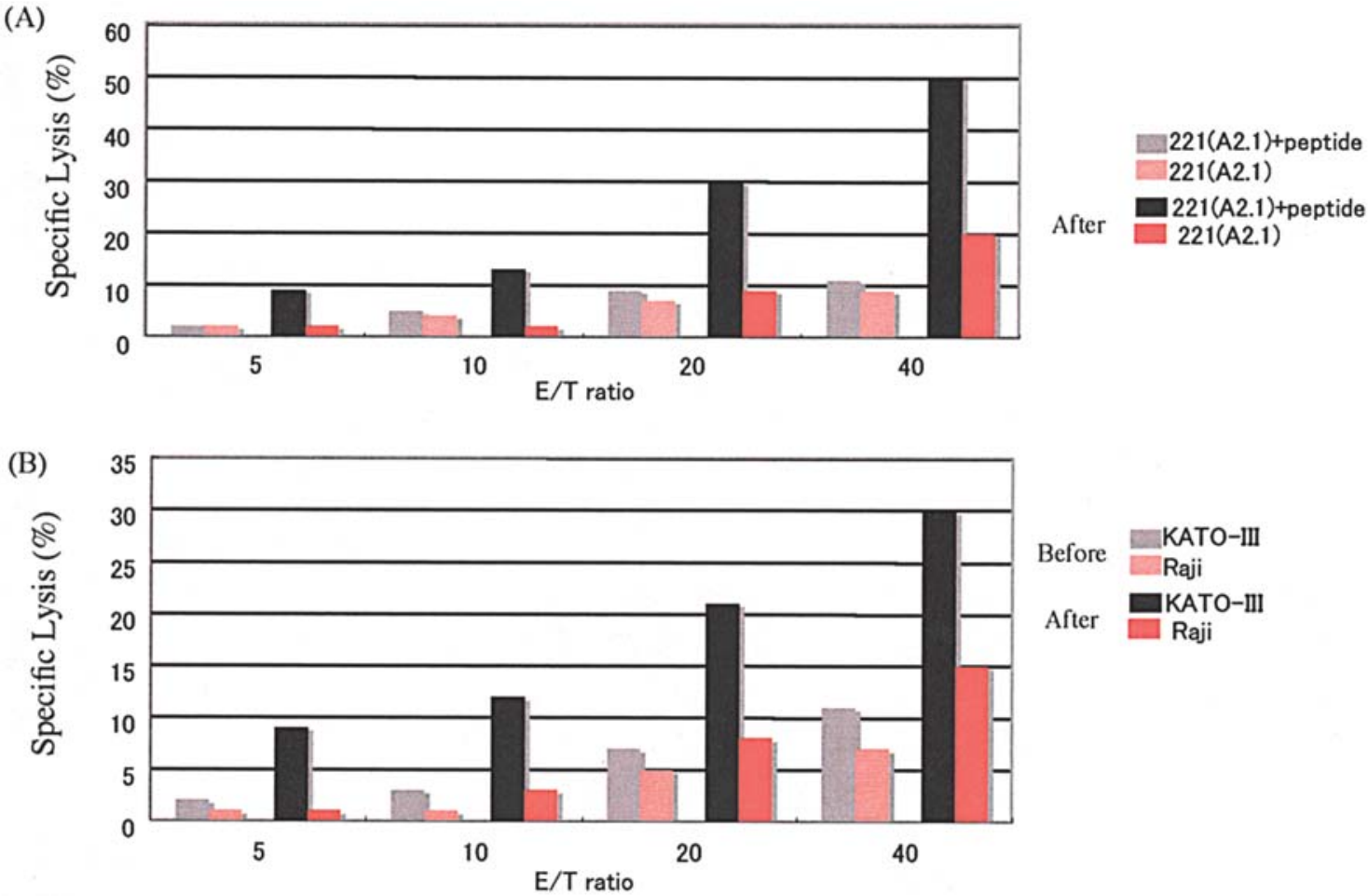

Figure 2. DCs/MAGE peptide vaccine enhanced immunological response against cells expressing MAGE-3 and HLA-A0201. PBMCs were obtained from patients before the first vaccination and after the final injection. (A) Cytolytic assay was performed against 221(A2.1) cells alone and 221(A2.1) cells pulsed with the MAGE peptide. (B) Cytolytic assay was performed against KATO-III cells (HLA-A0201-positive and MAGE-3-positive) and Raji cells (HLA-A0201-negative and MAGE-3-negative).

not present MAGE peptides at their surface. Therefore, immunotherapy with MAGE-derived antigens could avoid unexpected diseases such as autoimmune disease. Previous studies including ours indicated that no significant toxicity was observed in clinical trials with the MAGE-3 peptide for our gastrointestinal, melanoma patients and urinary bladder cancer patients $(15,16,28)$. This study also found no significant toxicity; therefore, the MAGE peptide is consistently considered as a good target for gastrointestinal carcinomas.

Based on our study, DCs pulsed with HLA-restricted peptides is also applicable for gastrointestinal carcinomas because of the general safety and feasibility of this approach, in addition to demonstrating an immunological and clinical response for several tumor types.

Mainly Th1 cells produce IFN- $\gamma$ and mediate cellular immune response, whereas Th2 cells produce mainly IL-4 and mediate humoral responses (29). Among T cells from PBMC in advanced gastrointestinal cancer patients, a Th2subset dominance was shown (30). In the present study, we observed the ratio of IFN- $\gamma / \mathrm{IL}-4$ of CD4-positive cells (Th1/Th2) increased after vaccination in some patients who had regression of tumor. These results indicate that a systemic cellular immune response may be induced in addition to a tumor-specific immune response in effective cases of DC vaccination. However, the increase of Th1/Th2 did not include all the patients who showed clinical benefits such as tumor marker decrease and/or tumor shrinkage. Further analysis is required to evaluate and predict the clinical benefits from immunological response. We performed some ELISPOT assays using PBMCs from these patients, however, the results indicate that the ELISPOT assay was not adequate to show a sensitive or specific effector response to the MAGE peptides (data not shown).

In the present study, peptide-specific immune responses were recognized in some patients by in vitro CTL precursor assay and DTH response. However, there is no direct evidence of a correlation between the immune response and clinical tumor regression. In the future, consideration should be given to this type of immunotherapy with other treatment strategies to achieve a greater vaccine effect. To avoid the negative effect on DC vaccine mediated by CD4 ${ }^{+} / \mathrm{CD} 25^{+}$Tregs, depletion of them using a recombinant IL-2 diphtheria toxin conjugate $\mathrm{DAB}_{389} \mathrm{IL}-2$ in human cancer patients (31), or murine model (32) was reported to be effective. We are planning the next clinical trial to assess whether vaccine therapy may become another modality for adjuvant treatment of gastrointestinal carcinomas at high risk for recurrence after operation, such as combination with or without chemotherapy or radiotherapy. To discover new markers to predict the good candidate for immunotherapy is crucial, because this approach could achieve clinical benefits for patients with advanced gastrointestinal cancer.

\section{Acknowledgements}

We would like to thank Ms. T. Shimooka, K. Ogata, M. Oda and Y. Nakagawa from our laboratory for their excellent technical assistance. This study was supported in Grant sponsor: CREST JST; Uehara Memorial Foundation; Grants-in-Aid for development of far advanced medicine 
(B), The ministry of Education, Culture, Sports, Science and Technology of Japan, Japan Society for the Promotion of Science (JSPS) Grant-in-Aid for Scientific Research; Grant numbers 17015032, 17109013, 17591411, 17591413, 17015032 and 16390381 and grants for developing faradvanced medical treatment (B) (2003-2005).

\section{References}

1. Greenlee RT, Murray T, Bolden S and Wingo PA: Cancer statistics, 2000. CA Cancer J Clin 50: 7-33, 2000.

2. Crew KD and Neugut AI: Epidemiology of upper gastrointestinal malignancies. Semin Oncol 31: 450-464, 2004.

3. De Smet C, De Backer O, Faraoni I, Lurquin C, Brasseur F and Boon T: The activation of human gene MAGE-1 in tumor cells is correlated with genome-wide demethylation. Proc Natl Acad Sci USA 93: 7149-7153, 1996.

4. Traversari C, van der Bruggen P, Luescher IF, Lurquin C, Chomez P, Van Pel A, De Plaen E, Amar CA and Boon T: A nonapeptide encoded by human gene MAGE-1 is recognized on HLA-A1 by cytolytic T lymphocytes directed against tumor antigen MZ2-E. J Exp Med 176: 1453-1457, 1992

5. Gaugler B, Van den Eynde B, van der Bruggen P, Romero P, Gaforio JJ, De Plaen E, Lethe B, Brasseur F and Boon T: Human gene MAGE-3 codes for an antigen recognized on a melanoma by autologous cytolytic T lymphocytes. J Exp Med 179: 921-930, 1994.

6. van der Bruggen P, Bastin J, Gajewski T, Coulie PG, Boel P, De Smet C, Traversari C, Townsend A and Boon T: A peptide encoded by human gene MAGE-3 and presented by HLA-A2 induces cytolytic $\mathrm{T}$ lymphocytes that recognize tumor cells expressing MAGE-3. Eur J Immunol 24: 3038-3043, 1994.

7. Herman J, van der Bruggen P, Luescher IF, Mandruzzato S, Romero P,Thonnard J, Fleischhauer K, Boon T and Coulie PG: A peptide encoded by the human MAGE3 gene and presented by HLA-B44 induces cytolytic T lymphocytes that recognize tumor cells expressing MAGE3. Immunogenetics 43: 377-383, 1996.

8. Tanaka F, Fujie T, Tahara K, Mori M, Takesako K, Sette A, Celis $\mathrm{E}$ and Akiyoshi T: Induction of antitumor cytotoxic $\mathrm{T}$ lymphocytes with a MAGE-3-encoded synthetic peptide presented by human leukocytes antigen-A24. Cancer Res 57: 4465-4468, 1997.

9. Mukherji B, Chakraborty NG, Yamasaki S, Okino T, Yamase H, Sporn JR, Kurtzman SK, Ergin MT, Ozols J, Meehan J and Mauri F: Induction of antigen-specific cytolytic T cells in situ in human melanoma by immunization with synthetic peptide-pulsed autologous antigen presenting cells. Proc Natl Acad Sci USA 92: 8078-8082, 1995.

10. Weber JS, Hua FL, Spears L, Marty V, Kuniyoshi C and Celis E: A Phase I trial of an HLA-A1-restricted MAGE-3 epitope peptide with incomplete Freund's adjuvant in patients with resected high-risk melanoma. J Immunother 22: 431-440, 1999.

11. Marchand M, van Baren N, Weynants P, Brichard V, Dreno B, Tessier MH, Rankin E, Parmiani G, Arienti F, Humblet Y, Bourlond A, Vanwijck R, Lienard D, Beauduin M, Dietrich PY, Russo V, Kerger J, Masucci G, Jager E, De Greve J, Atzpodien J, Brasseur F, Coulie PG, van der Bruggen P and Boon T: Tumor regressions observed in patients with metastatic melanoma treated with an antigenic peptide encoded by gene MAGE-3 and presented by HLA-A1. Int J Cancer 80: 219-230, 1999.

12. Timmerman JM and Levy R: Dendritic cell vaccines for cancer immunotherapy. Annu Rev Med 50: 507-529, 1999.

13. Evel-Kabler K and Chen SY: Dendritic cell-based tumor vaccines and antigen presentation attenuators. Mol Ther 13: 850-858, 2006.

14. Nestle FO, Alijagic S, Gilliet M, Sun Y, Grabbe S, Dummer R, Burg G and Schadendorf D: Vaccination of melanoma patients with peptide- or tumor lysate-pulsed dendritic cells. Nat Med 4: 328-332, 1998.

15. Thurner B, Haendle I, Roder C, Dieckmann D, Keikavoussi P, Jonuleit H, Bender A, Maczek C, Schreiner D, von den Driesch P, Brocker EB, Steinman RM, Enk A, Kampgen E and Schuler G: Vaccination with Mage-3A1 peptide-pulsed mature, monocytederived dendritic cells expands specific cytotoxic $T$ cells and induces regression of some metastases in advanced stage IV melanoma. J Exp Med 190: 1669-1678, 1999.
16. Sadanaga N, Nagashima H, Mashino K, Tahara K, Yamaguchi H, Ohta M, Fujie T, Tanaka F, Inoue H, Takesako K, Akiyoshi T and Mori M: Dendritic cell vaccination with MAGE peptide is a novel therapeutic approach for gastrointestinal carcinomas. Clin Cancer Res 7: 2277-2284, 2001.

17. Inoue H, Mori M, Honda M, Li J, Shibuta K, Mimori K, Ueo H and Akiyoshi T: The expression of tumor-rejection antigen 'MAGE' genes in human gastric carcinoma. Gastroenterology 109: 1522-1525, 1995.

18. Bednarek MA, Sauma SY, Gammon MC, Porter G, Tamhankar S, Williamson R and Zweerink HJ: The minimum peptide epitope from the influenza virus matrix protein. Extra and intracellular loading of HLA-A2. J Immunol 147: 4047-4053, 1991.

19. Jaeger E, Bernhard H, Romero P, Ringhoffer M, Arand M, Karbach J, Ilsemann C, Hagedorn M and Knuth A: Generation of cytotoxic T-cell responses with synthetic melanomaassociated peptides in vivo: implications for tumor vaccines with melanoma-associated antigens. Int J Cancer 66: 162-169, 1996.

20. Picker LJ, Singh MK, Zdraveski Z, Treer JR, Waldrop SL, Bergstresser PR and Maino VC: Direct demonstration of cytokine synthesis heterogeneity among human memory/ effector T cells by flow cytometry. Blood 86: 1408-1419, 1995.

21. Thomas-Kaskel AK, Zeiser R, Jochim R, Robbel C, Schultze-Seemann W, Waller CF and Veelken H: Vaccination of advanced prostate cancer patients with PSCA and PSA peptide-loaded dendritic cells induces DTH responses that correlate with superior overall survival. Int J Cancer 119: 2428-2434, 2006.

22. Mittendorf EA, Storrer CE, Foley RJ, Harris K, Jama Y, Shriver CD, Ponniah S and Peoples GE: Evaluation of the HER2/neu-derived peptide GP2 for use in a peptide-based breast cancer vaccine trial. Cancer 106: 2309-2317, 2006.

23. Babatz J, Rollig C, Lobel B, Folprecht G, Haack M, Gunther H, Kohne CH, Ehninger G, Schmitz M, Bornhauser M: Induction of cellular immune responses against carcinoembryonic antigen in patients with metastatic tumors after vaccination with altered peptide ligand-loaded dendritic cells. Cancer Immunol Immunother 55: 268-276, 2006.

24. Liu KJ, Wang CC, Chen LT, Cheng AL, Lin DT, Wu YC, Yu WL, Hung YM, Yang HY, Juang SH and Whang-Peng J: Generation of carcinoembryonic antigen (CEA)-specific T-cell responses in HLA-A*0201 and HLA-A*2402 late-stage colorectal cancer patients after vaccination with dendritic cells loaded with CEA peptides. Clin Cancer Res 10: 2645-2651, 2004.

25. Eckel F, Schneider G and Schmid RM: Pancreatic cancer: a review of recent advances. Expert Opin Investig Drugs 15: 1395-1410, 2006

26. Sikora SS and Singh RK: Surgical strategies in patients with gallbladder cancer: nihilism to optimism. J Surg Oncol 93: 670-681, 2006.

27. Steinman RM and Hemmi H: Dendritic cells: translating innate to adaptive immunity. Curr Top Microbiol Immunol 311: 17-58, 2006.

28. Nishiyama T, Tachibana M, Horiguchi Y, Nakamura K, Ikeda Y, Takesako K and Murai M: Immunotherapy of bladder cancer using autologous dendritic cells pulsed with human lymphocyte antigen-A24-specific MAGE-3 peptide. Clin Cancer Res 7: 23-31, 2001.

29. Fiorentino DF, Bond MW and Mosmann TR: Two types of mouse T helper cell. IV. Th2 clones secrete a factor that inhibits cytokine production by Th1 clones. J Exp Med 170: 2081-2095, 1989.

30. Matsuda A, Furukawa K, Takasaki H, Suzuki H, Kan H, Tsuruta H, Shinji S and Tajiri T: Preoperative oral immuneenhancing nutritional supplementation corrects TH1/TH2 imbalance in patients undergoing elective surgery for colorectal cancer. Dis Colon Rectum 49: 507-516, 2006

31. Dannull J, Su Z, Rizzieri D, Yang BK, Coleman D, Yancey D, Zhang A, Dahm P, Chao N, Gilboa E and Vieweg J: Enhancement of vaccine-mediated antitumor immunity in cancer patients after depletion of regulatory T cells. J Clin Invest 115: 3623-3633, 2005

32. Van Meirvenne S, Dullaers M, Heirman C, Straetman L, Michiels A and Thielemans K: In vivo depletion of CD4 ${ }^{+}$ $\mathrm{CD} 25^{+}$regulatory $\mathrm{T}$ cells enhances the antigen-specific primary and memory CTL response elicited by mature mRNAelectroporated dendritic cells. Mol Ther 12: 922-932, 2005. 